\title{
Transient early wheeze and lung function in early childhood associated with chronic obstructive pulmonary disease genes
}

Citation for published version (APA):

Kerkhof, M., Boezen, H. M., Granell, R., Wijga, A. H., Brunekreef, B., Smit, H. A., de Jongste, J. C., Thijs, C., Mommers, M., Penders, J., Henderson, J., Koppelman, G. H., \& Postma, D. S. (2014). Transient early wheeze and lung function in early childhood associated with chronic obstructive pulmonary disease genes. Journal of Allergy and Clinical Immunology, 133(1), 68-76.e4. https://doi.org/10.1016/j.jaci.2013.06.004

Document status and date:

Published: 01/01/2014

DOI:

10.1016/j.jaci.2013.06.004

Document Version:

Publisher's PDF, also known as Version of record

\section{Document license:}

Taverne

Please check the document version of this publication:

- A submitted manuscript is the version of the article upon submission and before peer-review. There can be important differences between the submitted version and the official published version of record.

People interested in the research are advised to contact the author for the final version of the publication, or visit the DOI to the publisher's website.

- The final author version and the galley proof are versions of the publication after peer review.

- The final published version features the final layout of the paper including the volume, issue and page numbers.

Link to publication

\footnotetext{
General rights rights.

- You may freely distribute the URL identifying the publication in the public portal. please follow below link for the End User Agreement:

www.umlib.nl/taverne-license

Take down policy

If you believe that this document breaches copyright please contact us at:

repository@maastrichtuniversity.nl

providing details and we will investigate your claim.
}

Copyright and moral rights for the publications made accessible in the public portal are retained by the authors and/or other copyright owners and it is a condition of accessing publications that users recognise and abide by the legal requirements associated with these

- Users may download and print one copy of any publication from the public portal for the purpose of private study or research.

- You may not further distribute the material or use it for any profit-making activity or commercial gain

If the publication is distributed under the terms of Article $25 \mathrm{fa}$ of the Dutch Copyright Act, indicated by the "Taverne" license above, 


\title{
Transient early wheeze and lung function in early childhood associated with chronic obstructive pulmonary disease genes $^{2}$
}

\author{
Marjan Kerkhof, MD, PhD, ${ }^{\mathrm{a}, \mathrm{b}}$ H. Marike Boezen, $\mathrm{PhD},{ }^{\mathrm{a}, \mathrm{b}}$ Raquel Granell, PhD, ${ }^{\mathrm{c}}$ Alet H. Wijga, PhD, ${ }^{\mathrm{d}}$ Bert Brunekreef, PhD,

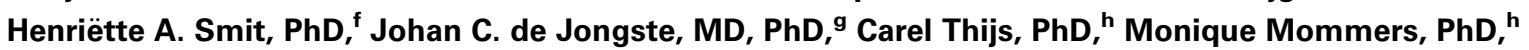 \\ John Penders, PhD, ${ }^{\mathrm{h}}$ John Henderson, MD, ${ }^{\mathrm{C}}$ Gerard H. Koppelman, MD, PhD, ${ }^{\mathrm{i}}$ and Dirkje S. Postma, MD, PhD ${ }^{\mathrm{j}}$ Groningen, \\ Bilthoven, Utrecht, Rotterdam, and Maastricht, The Netherlands, and Bristol, United Kingdom
}

Background: It has been hypothesized that a disturbed early lung development underlies the susceptibility to chronic obstructive pulmonary disease (COPD). Little is known about whether subjects genetically predisposed to COPD show their first symptoms or reduced lung function in childhood.

Objective: We investigated whether replicated genes for COPD associate with transient early wheeze (TEW) and lung function levels in 6- to 8-year-old children and whether cigarette smoke exposure in utero and after birth (environmental tobacco smoke [ETS]) modifies these effects.

Methods: The association of COPD-related genotypes of 20 single nucleotide polymorphisms in 15 genes with TEW, FEV , forced vital capacity (FVC), and $\mathrm{FEV}_{1} / \mathrm{FVC}$ ratio was studied in the Prevention and Incidence of Asthma and Mite Allergy (PIAMA) birth cohort $(n=1996)$ and replicated in the Child, parents and health: lifestyle and genetic constitution (KOALA) and Avon Longitudinal Study of Parents and Children (ALSPAC) cohorts.

\footnotetext{
From the Departments of ${ }^{\mathrm{a}}$ Epidemiology, ${ }^{\mathrm{i}}$ Paediatric Pulmonology, and ${ }^{\mathrm{j}}$ Pulmonology, and ${ }^{b}$ the GRIAC Institute, University of Groningen, University Medical Center Groningen; ${ }^{c}$ the School of Social and Community Medicine, University of Bristol; ${ }^{d}$ the Centre for Prevention and Health Services Research, National Institute for Public Health and the Environment, Bilthoven; ${ }^{e}$ the Institute for Risk Assessment Science, Utrecht University; ${ }^{\mathrm{f}}$ the Julius Center for Health Sciences and Primary Care, University Medical Center Utrecht; ${ }^{\mathrm{g}}$ the Department of Pediatrics, Division of Respiratory Medicine, Erasmus University Medical Center/Sophia Children's Hospital, Rotter dam; and ${ }^{\text {h }}$ the Department of Epidemiology, Maastricht University School for Public Health and Primary Care CAPHRI, Maastricht.

This is an open-access article distributed under the terms of the Creative Commons Attribution License, which permits unrestricted use, distribution, and reproduction in any medium, provided the original author and source are credited.

Supported by the Dutch Asthma Foundation (grant 3.2.09.043); ZonMw (the Netherlands Organization for Health Research and Development); the Netherlands Ministry of Spatial Planning, Housing and the Environment; and the Netherlands Ministry of Health, Welfare and Sport. The UK Medical Research Council, Wellcome Trust (grant 092731), and the University of Bristol provided core support for the Avon Longitudinal Study of Parents and Children (ALSPAC).

Disclosure of potential conflict of interest: M. Kerkhof has received grants from the Dutch Asthma Foundation. C. Thijs has received grants from the Netherlands Asthma Foundation. J. Henderson has received grants from the Wellcome Trust and the Medical Research Council. G. H. Koppelman has received grants from the Netherlands Asthma Foundation and Stichting Asthma Bestrijding. D. S. Postma has consultant arrangements with AstraZeneca, Boehringer, Chiesi, Nycomed, and TEVA and has received grants from AstraZeneca and Chiesi. The rest of the authors declare that they have no relevant conflicts of interest.

Received for publication December 3, 2012; revised May 1, 2013; accepted for publication June 5, 2013.

Available online July 22, 2013.

Corresponding author: Marjan Kerkhof, MD, PhD, Department of Epidemiology, University Medical Center Groningen, University of Groningen, Hanzeplein 1, Groningen 9713 GZ, The Netherlands. E-mail: m.kerkhof@umcg.nl.

0091-6749

(c) 2013 The Authors. Published by Elsevier Inc. All rights reserved.

http://dx.doi.org/10.1016/j.jaci.2013.06.004
}

Results: $A G E R$ showed replicated association with $\mathrm{FEV}_{1} / \mathrm{FVC}$ ratio. TNS1 associated with more TEW in PIAMA and lower FEV in ALSPAC. TNS1 interacted with ETS in PIAMA, showing lower FEV $_{1}$ in exposed children. HHIP rs1828591 interacted with cigarette smoke exposure in utero in PIAMA and with ETS in ALSPAC, with lower lung function in nonexposed children. SERPINE2, FAM13A, and MMP12 associated with higher FEV and FVC, and SERPINE2, HHIP, and TGFB1 interacted with cigarette smoke exposure in utero in PIAMA only, showing adverse effects of exposure on $\mathrm{FEV}_{1}$ being limited to children with genotypes conferring the lowest risk of COPD.

Conclusion: Our findings indicate relevant involvement of at least 3 COPD genes in lung development and lung growth by demonstrating associations pointing toward reduced airway caliber in early childhood. Furthermore, our results suggest that COPD genes are involved in the infant's lung response to smoke exposure in utero and in early life. (J Allergy Clin Immunol 2014;133:68-76.)

Key words: Chronic obstructive pulmonary disease, transient early wheeze, lung function growth, in utero exposure

More than 30 years ago, Burrows suggested that disturbed early development of the lungs might underlie the susceptibility to chronic obstructive pulmonary disease (COPD), a hypothesis that has recently been put forward again by several researchers. ${ }^{1-3}$ There is suggestive epidemiologic evidence that early-life events program a child to be at increased risk for future COPD development. ${ }^{4}$ Oxidant pollutants have been shown to influence both lung development in utero and growth and maturation of the lungs after birth. ${ }^{5}$ Additionally, in utero exposure to maternal tobacco smoke results in deficits in lung function measured soon after birth, which can persist from childhood to adult life. ${ }^{6}$ Postnatal exposure to tobacco smoke might have an additional adverse effect on lung growth, although conflicting findings have been reported. ${ }^{7,8}$

COPD can have not only its origins but also its first signs and symptoms in early childhood, which might offer opportunities for early identification of subjects susceptible to COPD. Several studies have shown that an early-life history of respiratory disease increases the mortality caused by COPD. ${ }^{2,9}$ Especially the occurrence of transient early wheeze (TEW) in childhood can constitute a first sign of disturbed early lung development and lung growth because TEW has been shown to associate with reduced lung function already soon after birth, which is probably caused by genetic constitution, in utero exposures (eg, cigarette smoke), or both. ${ }^{10}$ Furthermore, these airway developmental abnormalities related to TEW have been shown to associate with lower lung function when symptoms have disappeared, which then 
Abbreviations used

ALSPAC: Avon Longitudinal Study of Parents and Children

COPD: Chronic obstructive pulmonary disease

ETS: Environmental tobacco smoke

FVC: Forced vital capacity

KOALA: Child, parents and health: lifestyle and genetic constitution OR: Odds ratio

PIAMA: Prevention and Incidence of Asthma and Mite Allergy

RAGE: Receptor for advanced glycation end products

SNP: Single nucleotide polymorphism

TEW: Transient early wheeze

persists through the rest of childhood and adolescence. ${ }^{11-14}$ Hence TEW might relate to later development of COPD. Our hypothesis is that COPD genes influence structural and functional airway development in utero and hence the occurrence of TEW and that the presence of TEW might be a forerunner of a lifelong lower-thanaverage lung function in a subset of children, eventually predisposing them to COPD.

A major limiting factor in research on the hypothesis that COPD has its origins in early childhood is the huge logistic difficulty of studying the effect of early-life events with respect to a disorder that only becomes apparent 50 to 60 years later. Therefore research must rely on indirect evidence, which can be obtained by investigating potential common underlying genes. We have previously published data connecting genes that are important for lung growth, such as $A D A M 33$, with susceptibility to COPD. ${ }^{15,16}$ We here show our investigation into whether replicated genes associated with COPD are additionally associated with TEW, the phenotype that is most relevant to our hypothesis, because it is characterized by a reduced lung function in later childhood, as well as with the level of lung function in children in the Prevention and Incidence of Asthma and Mite Allergy (PIAMA) birth cohort and replicated significant associations in the KOALA and Avon Longitudinal Study of Parents and Children (ALSPAC) cohorts.

\section{METHODS \\ Study populations}

The PIAMA, KOALA, and ALSPAC birth cohorts have been described in detail elsewhere. ${ }^{17-19}$ A description of the selection of the study populations is provided in the Methods section in this article's Online Repository at www. jacionline.org. Children with a mother of non-Dutch origin were excluded from the analyses.

Complete data on spirometry and genotypes were available for 914 PIAMA children, 366 KOALA children, and 4851 ALSPAC children (Table I).

\section{Single nucleotide polymorphism selection and genotyping}

We searched the literature up to March 2010 and selected 21 single nucleotide polymorphisms (SNPs) fulfilling 1 or more of the following criteria in white populations:

1. Replicated SNPs from genome-wide association studies on COPD, $\mathrm{FEV}_{1}$, or $\mathrm{FEV}_{1} /$ forced vital capacity (FVC) ratio;

2. SNPs significantly associated with COPD in a published meta-analy$\operatorname{sis}^{20}$; and

3. SNPs published to show significant association with COPD in 3 or more independent populations.

We selected SNPs in the following 15 genes: $\operatorname{SFTPB},{ }^{21} T N S 1,{ }^{22}$

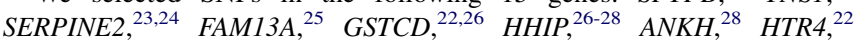
AGER,${ }^{22,26}$ MMP12, ${ }^{29}$ THSD $4,{ }^{22}$ IREB $2,{ }^{30}$ AGPHD $1,{ }^{28}$ CHRNA3, ${ }^{28}$ and $T G F B 1 .{ }^{20} \mathrm{SNP}$ (rs 1800470) in the TGFB1 gene failed genotyping. The 20 analyzed SNPs are shown in Table II. ${ }^{20-30}$ Genotyping methods and patterns of linkage disequilibrium (Table E1) within loci are described in the Methods section in this article's Online Repository. We have selected proxy-SNPs for unavailable SNPs in ALSPAC by using HapMap release $22^{31}$ : rs 975278 in SERPINE2 for rs729631 $\left(r^{2}=1\right)$ and rs6734100 $\left(r^{2}=0.82\right)$, rs 17368659 in $M M P 12$ for rs $2276109\left(r^{2}=1\right)$, and rs8109167 in TGFB1 for rs6957 $\left(r^{2}=1\right)$.

TABLE I. Characteristics of the birth cohorts

\begin{tabular}{|c|c|c|c|}
\hline & PIAMA & KOALA & ALSPAC \\
\hline No. genotyped & 1996 & 1572 & 4851 \\
\hline Male sex & $51.6(1030)$ & $50.4(792)$ & $50.6(2455)$ \\
\hline Mother allergic & 37.5 (749) & $32.9(517)$ & $47.7(2220)$ \\
\hline Father allergic & $30.8(615)$ & $36.5(562)$ & $40.2(1410)$ \\
\hline Mother smoking during pregnancy & $12.0(240)$ & $4.4(69)$ & $19.6(915)$ \\
\hline ETS exposure in first year & $25.0(477)$ & $11.4(168)$ & $34.7(1210)$ \\
\hline Older siblings at birth & $51.7(927)$ & $58.4(901)$ & $52.9(2440)$ \\
\hline Day care attendance & $24.6(489)$ & $35.4(538)$ & $11.1(489)$ \\
\hline Premature birth & $4.6(91)$ & $3.7(58)$ & $5.0(234)$ \\
\hline \multicolumn{4}{|l|}{ Duration of breast-feeding } \\
\hline Never & $15.7(311)$ & $14.7(231)$ & $17.7(793)$ \\
\hline$<3 \mathrm{mo}$ & $35.6(706)$ & $20.7(325)$ & $30.6(1375)$ \\
\hline$\geq 3 \mathrm{mo}$ & $48.7(967)$ & $64.6(1016)$ & $51.8(2326)$ \\
\hline \multicolumn{4}{|l|}{ Mother's educational level } \\
\hline Low & $20.0(398)$ & $8.4(126)$ & $20.1(949)$ \\
\hline Intermediate & $42.3(842)$ & $37.3(561)$ & $34.3(1615)$ \\
\hline High & $37.7(751)$ & $54.4(818)$ & $45.6(2151)$ \\
\hline \multicolumn{4}{|l|}{ Wheezing phenotypes } \\
\hline Never wheeze & $60.2(1132)$ & $63.2(773)$ & $68.7(2023)$ \\
\hline TEW & $22.8(429)$ & $22.2(272)$ & $31.3(921)$ \\
\hline $\mathrm{FEV}_{1}(\%$ predicted $)$, mean $\pm \mathrm{SD}(\mathrm{n})$ & $104.0 \pm 10.8(914)$ & $96.4 \pm 11.5(366)$ & $98.3 \pm 11.7(4851)$ \\
\hline FVC $(\%$ predicted $)$, mean $\pm \mathrm{SD}(\mathrm{n})$ & $102.7 \pm 10.9(914)$ & $101.4 \pm 11.7(366)$ & $97.7 \pm 11.9(4851)$ \\
\hline $\mathrm{FEV}_{1} / \mathrm{FVC}(\%$ predicted $)$, mean $\pm \mathrm{SD}(\mathrm{n})$ & $97.6 \pm 7.1(914)$ & $92.0 \pm 6.7(366)$ & $99.9 \pm 7.3(4851)$ \\
\hline
\end{tabular}

Values are presented as percentages (numbers) or means \pm SDs (numbers). 
TABLE II. Characteristics of the selected SNPs

\begin{tabular}{|c|c|c|c|c|c|c|c|c|c|}
\hline SNP & Nearest gene & Chromosome & Position & $\begin{array}{c}\text { Major > } \\
\text { minor allele }\end{array}$ & $\begin{array}{l}\text { MAF } \\
\text { PIAMA }\end{array}$ & $\begin{array}{l}\text { Risk } \\
\text { allele* }\end{array}$ & Function & Phenotype & References \\
\hline rs1130866 & $S F T P B$ & 2 & 85893741 & $\mathrm{~T}>\mathrm{C}$ & 0.47 & $\mathrm{C}$ & Missense & COPD & Hersh et $\mathrm{al}^{21}$ \\
\hline rs 2571445 & TNS1 & 2 & 218683154 & $\mathrm{C}>\mathrm{T}$ & 0.36 & $\mathrm{~T}$ & Missense & $\mathrm{FEV}_{1}$ & Repapi et $\mathrm{al}^{22}$ \\
\hline rs 729631 & SERPINE2 & 2 & 224844919 & $\mathrm{C}>\mathrm{G}$ & 0.16 & $\mathrm{C}$ & Intronic & COPD & $\begin{array}{l}\text { DeMeo et } \mathrm{al}^{23} \text { and } \\
\text { Zhu et } \mathrm{al}^{24}\end{array}$ \\
\hline rs 1032295 & HHIP & 4 & 145654034 & $\mathrm{~T}>\mathrm{G}$ & 0.40 & $\mathrm{~T}$ & Intergenic & $\mathrm{FEV}_{1} / \mathrm{FVC}$ & Hancock et $\mathrm{al}^{26}$ \\
\hline rs 1828591 & HHIP & 4 & 145700230 & $\mathrm{~A}>\mathrm{G}$ & 0.42 & A & Intergenic & $\mathrm{FEV}_{1} / \mathrm{FVC}, \mathrm{COPD}$ & $\begin{array}{c}\text { Wilk et } \mathrm{al}^{27} \text { and } \\
\text { Pillai et } \mathrm{al}^{28}\end{array}$ \\
\hline rs9686327 & $A N K H$ & 5 & 15071537 & $\mathrm{G}>\mathrm{A}$ & 0.17 & ? & Intergenic & COPD & Pillai et $\mathrm{al}^{28}$ \\
\hline rs 735243 & $A N K H$ & 5 & 15092327 & $\mathrm{G}>\mathrm{A}$ & 0.14 & $?$ & Intergenic & COPD & Pillai et $\mathrm{a}^{28}$ \\
\hline rs12899618 & THSD4 & 15 & 71645120 & $\mathrm{G}>\mathrm{A}$ & 0.17 & A & Intronic & $\mathrm{FEV}_{1} / \mathrm{FVC}$ & Repapi et $\mathrm{al}^{22}$ \\
\hline rs2568494 & IREB2 & 15 & 78740964 & $\mathrm{G}>\mathrm{A}$ & 0.31 & A & Intronic & COPD & DeMeo et $\mathrm{al}^{30}$ \\
\hline rs2656069 & IREB2 & 15 & 78745707 & $\mathrm{~T}>\mathrm{C}$ & 0.24 & $\mathrm{~T}$ & Intronic & COPD & DeMeo et $\mathrm{al}^{30}$ \\
\hline rs8034191 & AGPHD1 & 15 & 78806023 & $\mathrm{~T}>\mathrm{C}$ & 0.31 & $\mathrm{C}$ & Intronic & COPD & Pillai et $\mathrm{al}^{28}$ \\
\hline rs 1051730 & CHRNA3 & 15 & 78894339 & $\mathrm{C}>\mathrm{T}$ & 0.31 & $\mathrm{~T}$ & Exon: synonymous & COPD & Pillai et $\mathrm{al}^{28}$ \\
\hline rs6957 & $T G F B 1$ & 19 & 41830606 & $\mathrm{~T}>\mathrm{C}$ & 0.15 & $\mathrm{C}$ & $3^{\prime}$ UTR & COPD & Smolonska et $\mathrm{al}^{20}$ \\
\hline rs 1800469 & $T G F B 1$ & 19 & 41860296 & $\mathrm{~T}>\mathrm{C}$ & 0.30 & $\mathrm{~T}$ & Promoter & COPD & Smolonska et $\mathrm{al}^{20}$ \\
\hline
\end{tabular}

$M A F$, Minor allele frequency (proportion); UTR, untranslated region.

*Allele with highest risk of COPD or lowest lung function level; ? = risk alleles are inconsistently associated with COPD.

TABLE III. Association of SNPs in known COPD genes with TEW, FEV 1 , FVC, and FEV 1 /FVC ratio in the PIAMA study

\begin{tabular}{|c|c|c|c|c|c|c|}
\hline SNP & Nearest gene & Effect allele & Genetic model & Trait & Effect $(95 \% \mathrm{Cl})$ & $P$ value \\
\hline rs 2571445 & TNS1 & $\mathrm{T}$ & Additive & TEW & 1.24 (1.05 to 1.47$)$ & .014 \\
\hline \multirow[t]{2}{*}{ rs6734100 } & SERPINE2 & $\mathrm{C}$ & Dominant & $\mathrm{FEV}_{1}$ & $4.77(0.25$ to 9.29$)$ & .039 \\
\hline & & & & FVC & $5.52(0.92$ to 10.1$)$ & .019 \\
\hline & & & & FVC & $4.57(0.34$ to 8.81$)$ & .034 \\
\hline \multirow[t]{2}{*}{ rs7671167 } & FAM13A & $\mathrm{T}$ & Recessive & $\mathrm{FEV}_{1}$ & $2.02(0.33$ to 3.70$)$ & .019 \\
\hline & & & & FVC & $2.33(0.64$ to 4.03$)$ & .007 \\
\hline rs2276109 & $M M P 12$ & A & Dominant & FVC & $11.21(1.60$ to 20.8$)$ & .022 \\
\hline
\end{tabular}

Results are presented as ORs for TEW and as the mean difference in $\mathrm{FEV}_{1}$ or FVC percent predicted between children with and without the effect genotype.

\section{Outcome and exposure variables}

TEW was defined as parentally reported wheeze in the last 12 months at age 1 or 2 years but not at age 4 and 6 years because KOALA only collected data at these time points. Children without wheeze at ages 1, 2, 4, and 6 years served as the reference group. $\mathrm{FEV}_{1}$ and $\mathrm{FVC}$ were measured at age 8 years in PIAMA and ALSPAC and age 6 years in KOALA by using spirometry, with the methods detailed in the Methods section in this article's Online Repository. Percent predicted $\mathrm{FEV}_{1}, \mathrm{FVC}$, and the $\mathrm{FEV}_{1} / \mathrm{FVC}$ ratio were calculated according to previously published prediction equations. ${ }^{32}$

Maternal smoking during pregnancy was defined as smoking by the mother in the last trimester of pregnancy. Environmental tobacco smoke (ETS) exposure in the first year was defined as smoking of any household member in the house in PIAMA, smoking in the vicinity of the child in KOALA, and parental smoking during the first year of the child's life in ALSPAC.

\section{Statistical analysis}

Genetic association testing for each SNP separately was performed by using a codominant (general) model. Only when the overall $P$ value was less than .10 was the best fitting genetic model (dominant, recessive, or additive) further explored. Logistic and linear regression analysis was performed by analyzing TEW and lung function parameters as the outcome, respectively. Gene-smoke exposure interactions were tested for significance $(P<.05)$ by including an interaction term in the regression models. The presence of relevant confounding of the associations was evaluated by including variables (day care attendance, the presence of older siblings, and sex) in the regression model. No variables caused a greater than $10 \%$ change in coefficients. Therefore we did not include any covariates in the presented models. These analyses were performed in both PIAMA and KOALA. Results from KOALA are presented in the Methods section in this article's Online Repository; because lung function was available only in a small proportion of that population $(n=366)$, we could not draw firm conclusions.

SNPs showing significant associations were tested for main associations or interactions for all outcomes using imputed dosages, which would be equivalent to additive genetic models in ALSPAC. Associations were considered replicated when a significant effect in the same direction was observed for any of the outcomes. 


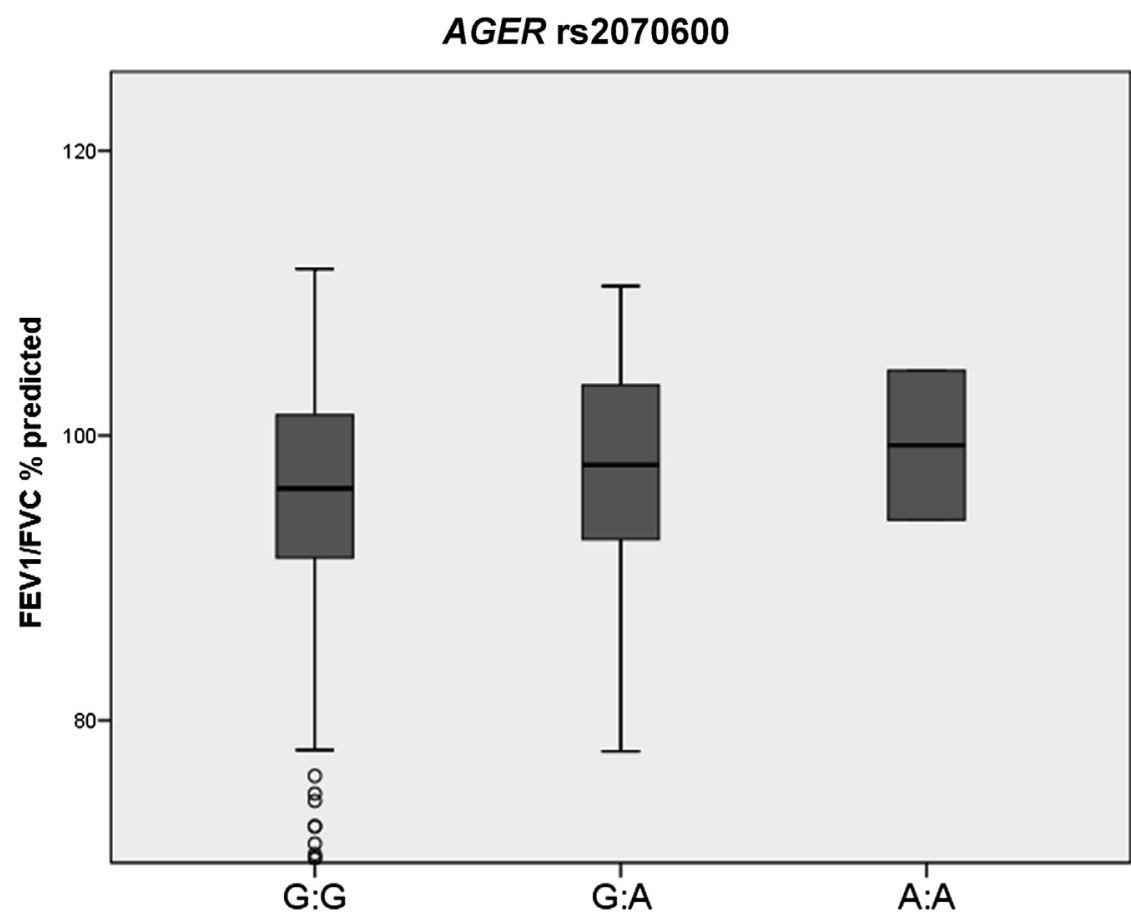

FIG 1. Box plot of FEV $/$ FVC percent predicted by genotype of $A G E R$ rs2070600 in PIAMA.

TABLE IV. Significant interaction of SNPs in COPD genes with maternal smoking during pregnancy or environmental smoke exposure in the first year of life with respect to lung function parameters observed in PIAMA

\begin{tabular}{|c|c|c|c|c|c|c|c|c|c|c|}
\hline \multirow[b]{3}{*}{ SNP } & \multirow[b]{3}{*}{ Nearest gene } & \multirow{3}{*}{$\begin{array}{l}\text { Effect } \\
\text { allele }\end{array}$} & \multirow{3}{*}{$\begin{array}{c}\text { Genetic } \\
\text { model }\end{array}$} & \multirow[b]{3}{*}{ Trait } & \multicolumn{6}{|c|}{ Effect $(95 \% \mathrm{Cl})$ of genotype on lung function (in presence or absence of exposure) } \\
\hline & & & & & \multicolumn{3}{|c|}{ Maternal smoking during pregnancy } & \multicolumn{3}{|c|}{ Environmental smoke in first year } \\
\hline & & & & & Yes & No & $P$-int & Yes & No & $P$-int \\
\hline rs729631 & SERPINE2 & $\mathrm{C}$ & Recessive & FVC & $\begin{array}{c}6.22 \\
(1.35 \text { to } 11.1)\end{array}$ & $\begin{array}{c}-0.76 \\
(-2.52 \text { to } 1.00)\end{array}$ & .008 & $\begin{array}{c}2.98 \\
(-0.31 \text { to } 6.26)\end{array}$ & $\begin{array}{c}-1.16 \\
(-3.11 \text { to } 0.79)\end{array}$ & .034 \\
\hline & & & & $\mathrm{FEV}_{1} / \mathrm{FVC}$ & $\begin{array}{c}5.58 \\
(1.76 \text { to } 9.39)\end{array}$ & $\begin{array}{c}-0.63 \\
(-2.06 \text { to } 0.79)\end{array}$ & .003 & & & \\
\hline \multirow[t]{2}{*}{ rs 1828591} & HHIP & A & Dominant & $\mathrm{FEV}_{1}$ & $\begin{array}{c}5.48 \\
(0.09 \text { to } 10.9)\end{array}$ & $\begin{array}{c}-2.58 \\
(-4.73 \text { to }-0.44)\end{array}$ & .006 & & & \\
\hline & & & & $\mathrm{FEV}_{1} / \mathrm{FVC}$ & $\begin{array}{c}4.46 \\
(0.93 \text { to } 7.99)\end{array}$ & $\begin{array}{c}-1.68 \\
(-3.08 \text { to }-0.27)\end{array}$ & .002 & & & \\
\hline
\end{tabular}

Results are presented as the mean difference in $\mathrm{FEV}_{1}$ or FVC percent predicted between children with and without the effect genotype.

$P$-int, $P$ value interaction term.

$P<.05$ (boldface).

\section{RESULTS}

The characteristics of the populations are shown in Table I. TEW was present in $23 \%, 22 \%$, and $31 \%$ of the children from PIAMA, KOALA, and ALSPAC, respectively. The mean FEV percent predicted was higher in PIAMA than in KOALA and ALSPAC.

\section{Main associations of COPD SNPs with TEW}

The TNS1 SNP rs2571445 (odds ratio [OR] per allele, 1.24 [95\% CI, 1.05 to 1.47]; $P=.01$ ) and the HHIP SNP rs1828591
(OR per allele, 1.27 [95\% CI, 1.07 to 1.50$] ; P=.005$ ) were significantly associated with TEW compared with the "never wheeze" category in PIAMA.

\section{Main effects of COPD SNPs on childhood lung function}

SNPs in 4 genes were significantly associated with $\mathrm{FEV}_{1}, \mathrm{FVC}$, or $\mathrm{FEV}_{1} / \mathrm{FVC}$ ratio (Table III). Children with 1 or more COPD risk alleles of the SERPINE2 SNPs or 2 risk alleles of the FAM13A 
TABLE V. Effects of different combinations of genotype and exposure on outcomes for SNPs involved in the response to oxidative stress significantly interacting with exposure

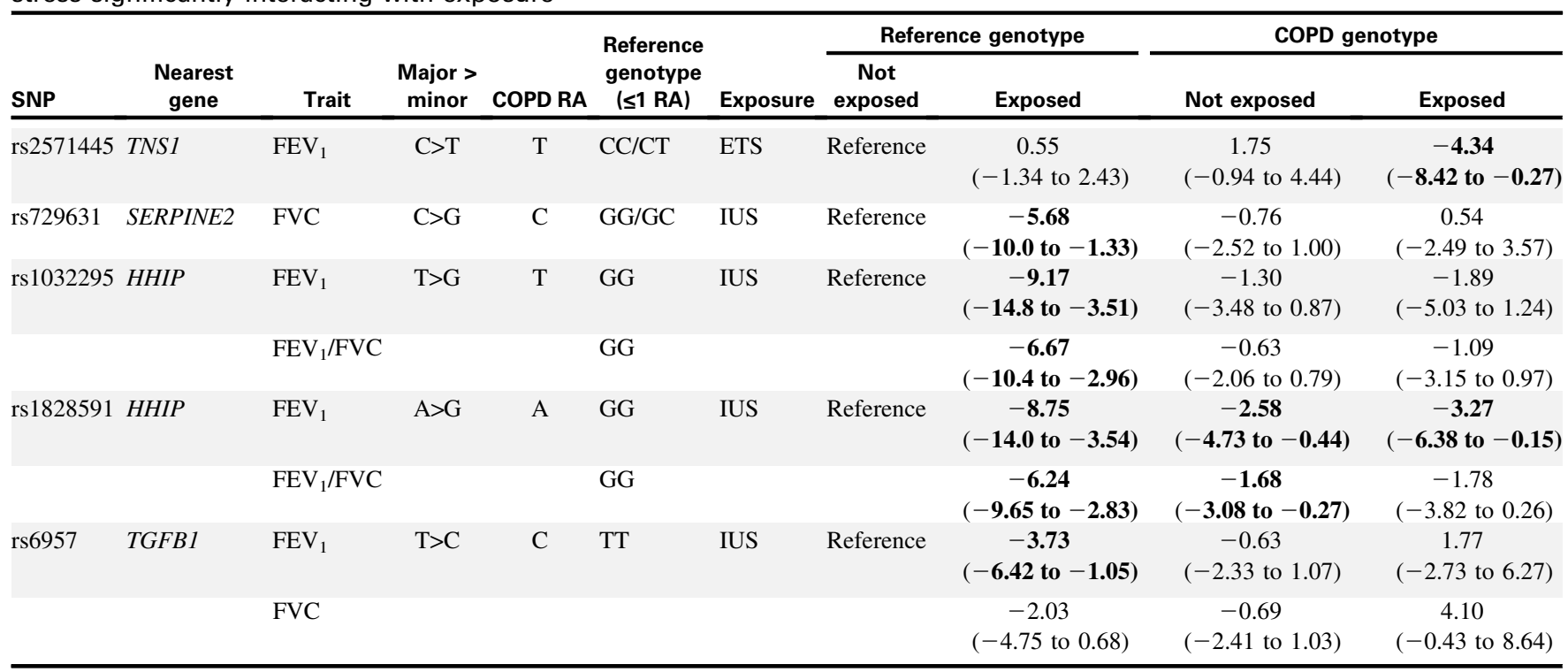

Effect estimates (95\% CIs) are presented for the specific combination compared with the reference group with 1 or fewer COPD risk alleles and without exposure calculated as ORs for TEW and the mean difference in percent predicted $\mathrm{FEV}_{1}, \mathrm{FVC}$, and $\mathrm{FEV}_{1} / \mathrm{FVC}$.

IUS, Cigarette smoke exposure in utero; $R A$, risk allele.

$P<.05$ (boldface).

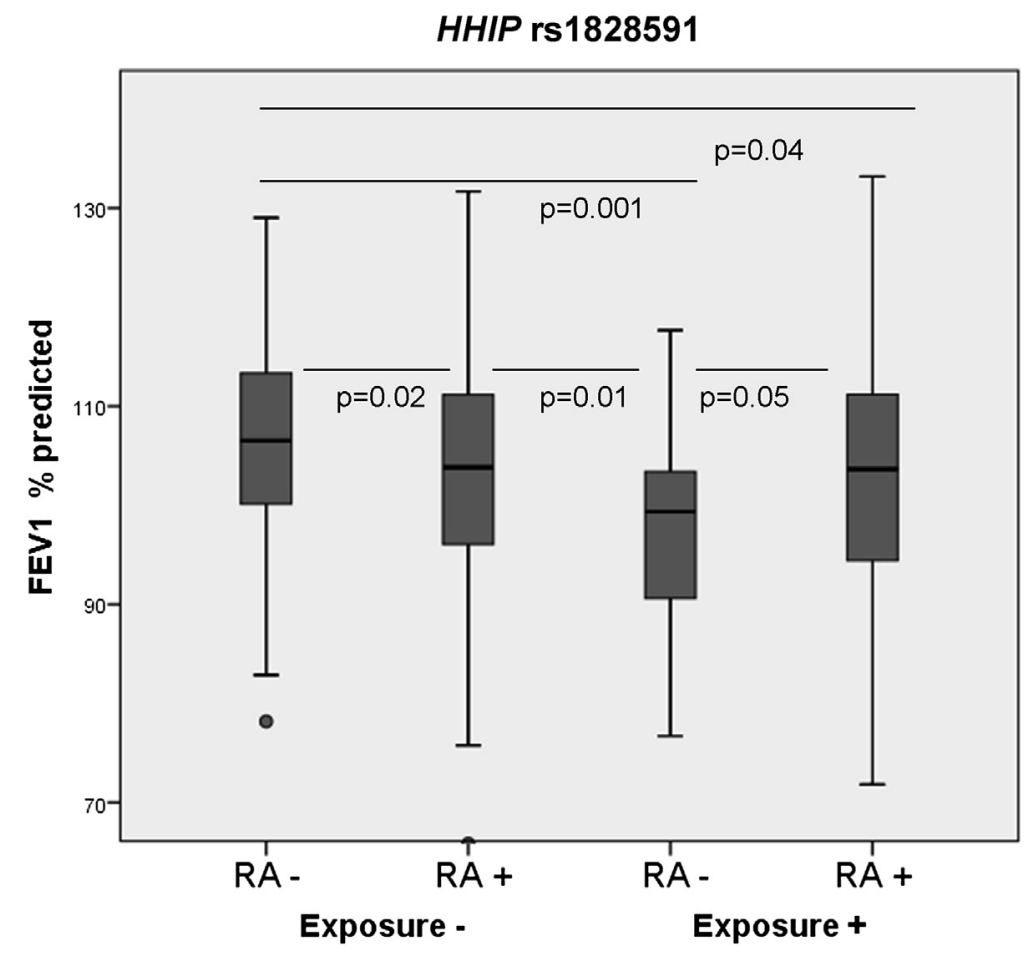

FIG 2. Box plots of $F_{E V}$ percent predicted for children without $(R A-)$ or with $(R A+)$ risk allele $A$ of $H H I P S N P$ rs1828591 in PIAMA stratified by exposure to maternal smoking during pregnancy.

SNP rs7671167 had a significantly higher mean $\mathrm{FEV}_{1}$ and FVC (Table III). Children with 1 or more COPD risk allele of MMP12 SNP rs2276109 had a significantly higher mean FVC than children without COPD risk alleles (Table III). A similar nonsignificant effect of $M M P 12$ was observed for $\mathrm{FEV}_{1}$.
The FVC was higher and the $\mathrm{FEV}_{1} / \mathrm{FVC}$ ratio was lower in children with a higher number of COPD risk alleles of the AGER SNP rs2070600 (Fig 1, and Table III). We found no association of the other genes with lung function. 


\section{Main associations of exposure with outcomes}

Maternal smoking during pregnancy was not significantly associated with TEW in PIAMA (OR, 1.1 [95\% CI, 0.8 to 1.5]; $P=.71)$. Mean $\mathrm{FEV}_{1}$ was significantly lower $(-2.3 \%$ [95\% CI, $-4.6 \%$ to $-0.1 \%$ ], $P=.04)$ in exposed children than in nonexposed children. Maternal smoking during pregnancy was not significantly associated with FVC (data not presented). ETS exposure in the house was not significantly associated with TEW or lung function levels. Associations of exposure with outcomes for the replication cohorts are shown in the Results section in this article's Online Repository at www.jacionline.org.

\section{Effect modification by maternal smoking during pregnancy}

SNPs in 3 genes interacted significantly with exposure to maternal smoking during pregnancy (Table IV). In utero exposure was only associated with lung function in children without (HHIP and $T G F B 1$ ) or with zero or 1 (SERPINE2) COPD risk alleles (Table V). As a result, COPD risk alleles of these genes were associated with better lung function in exposed children (Table IV). The presence of 2 COPD risk alleles of SERPINE2 SNP rs729631 was significantly associated with a higher mean FVC only in children exposed to maternal smoking during pregnancy (Table IV).

The presence of 1 or more COPD risk alleles of the HHIP SNPS rs1032295 or rs1828591 was associated with a significantly higher $\mathrm{FEV}_{1}$ and a higher $\mathrm{FEV}_{1} / \mathrm{FVC}$ ratio only in children whose mother smoked during pregnancy (Table IV). In nonexposed children a significant opposite effect was observed for rs1828591 (ie, the presence of $\geq 1$ COPD risk allele was associated with lower levels; Table IV). Both exposed and nonexposed children with 1 or more COPD risk alleles of rs 1828591 had significantly lower $\mathrm{FEV}_{1}$ levels than the reference group of nonexposed children without COPD risk alleles (Table V). Fig 2 shows this by showing the $\mathrm{FEV}_{1}$ levels for the 4 combinations of genotypes and exposure. Exposure was significantly associated with lower $\mathrm{FEV}_{1}$ levels in children without risk alleles and not in children with 1 or more risk alleles of rs 1828591.

The presence of COPD risk alleles of the TGFB1 SNP rs6957 was associated with higher $\mathrm{FEV}_{1}$ levels in children exposed to smoke in utero as well but not in children without exposure. A similar effect was found on FVC in children exposed to smoke in utero.

We found no significant interaction of the SNPs with maternal smoking during pregnancy in the association with TEW.

\section{Effect modification by tobacco smoke exposure after birth}

For the TNS1 SNP, significant interaction $(P=.03)$ with exposure was observed, showing worse lung function levels in children exposed to smoke in the home who had the genotype conferring a higher risk of COPD (Table V). Children with 2 COPD risk alleles exposed to smoke had the lowest mean $\mathrm{FEV}_{1}$ percent predicted, $5 \%$ lower than children exposed to smoke without the risk genotype (Tables IV and V).

SERPINE2 SNP rs729631 significantly $(P=.03)$ interacted with smoke exposure in the association with FVC in PIAMA (Table IV). ETS exposure was associated with a $6 \%$ lower FVC percent predicted in children without the COPD-related genotype (Table V).
We found no significant interaction between the SNPs and exposure to tobacco smoke in the first year of life in the association with TEW.

\section{Replication results}

In the ALSPAC study significant associations with lung function levels were found for 5 of the 7 associated COPD genes (Table VI). The main association of the AGER SNP rs2070600 with $\mathrm{FEV}_{1} / \mathrm{FVC}$ ratio was strictly replicated. The other significant associations in ALSPAC were observed for different outcomes, different genetic models, or different interacting exposures.

$\mathrm{FEV}_{1}$ decreased significantly with the number of COPD risk alleles of TNS1 in ALSPAC (Table VI). In PIAMA the risk of TEW increased with the number of COPD risk alleles, whereas the presence of 2 COPD risk alleles in TNS1 associated with lower FEV 1 levels in ETS-exposed children only (Tables IV and V).

The significant effects of SERPINE2 on $\mathrm{FEV}_{1}$ were opposite in direction in ALSPAC (Table VI) compared with PIAMA (Table III). The effect of HHIP rs1828591 on $\mathrm{FEV}_{1}$ and FVC was significantly modified by ETS exposure in the first year, with significantly lower FVC levels with increasing COPD risk alleles in ALSPAC children not exposed to ETS. In PIAMA effect modification in the same direction on $\mathrm{FEV}_{1}$ and $\mathrm{FEV}_{1} / \mathrm{FVC}$ ratio was observed for in utero smoke exposure.

For $M M P 12$, a higher number of COPD risk alleles was associated with a higher $\mathrm{FEV}_{1} / \mathrm{FVC}$ ratio in ALSPAC children in utero exposed to smoke. In PIAMA the presence of 1 or $2 M M P 12$ $\mathrm{COPD}$ risk alleles associated with a higher FVC in the total population.

None of the associations were replicated in KOALA (see the Results section in this article's Online Repository).

\section{DISCUSSION}

To our knowledge, this is the first study to test the hypothesis that genetic variants known to be associated with COPD and lower lung function in adults are associated with lung function and/or TEW, a marker of low lung function in early childhood. We found significant associations for 7 of the 15 genes in the PIAMA cohort; this was very unlikely to have occurred by chance. For 5 of these 7 genes, significant associations were observed with lung function levels in the ALSPAC cohort as well. COPD risk alleles of SNPs in TNS1, HHIP, and AGER pointed toward reduced airway caliber, as reflected by either TEW, lower $\mathrm{FEV}_{1}$, or lower $\mathrm{FEV}_{1} / \mathrm{FVC}$ ratio in both PIAMA and ALSPAC. Conversely, COPD risk alleles of SNPs in SERPINE2, FAM13A, and $M M P 12$ were associated with higher $\mathrm{FEV}_{1}$ and FVC in PIAMA, results that were not replicated and might be due to chance. Moreover, smoke exposure during pregnancy or early life significantly interacted with effects of SNPs in TNS1, SERPINE2, HHIP, $M M P 12$, and TGFB1 in PIAMA and with HHIP and MMP12 in ALSPAC. Thus our findings indicate relevant involvement of at least 3 COPD genes in lung development and lung growth.

The results for TNS1 and AGER are most consistent with findings in adults. Tensin 1 is involved in signal transduction and cell migration. ${ }^{33}$ The TNS1 locus at $2 \mathrm{q} 35$ was initially discovered in a genome-wide association study on $\mathrm{FEV}_{1}{ }^{22}$ The main hit rs2571445, a nonsynonymous coding SNP, has recently been reported to be associated with the presence of GOLD stage 2 to 4 COPD as well. ${ }^{33}$

Our findings on the AGER SNP rs2070600 affecting the $\mathrm{FEV}_{1} /$ FVC ratio are in line with the results from Hancock et al. ${ }^{26}$ The 
TABLE VI. Replication results in the ALSPAC cohort

\begin{tabular}{|c|c|c|c|c|c|c|}
\hline SNP & Nearest gene & Effect allele & MAF & Trait & Mean difference per allele & $P$ value \\
\hline \multirow[t]{2}{*}{ rs 2571445} & TNS1 & $\mathrm{A} \leftrightarrow \mathrm{T}$ & A $(0.40)$ & $\mathrm{FEV}_{1}$ & $-0.48(-0.96$ to -0.01$)$ & .047 \\
\hline & & & & FVC & $-0.47(-0.96$ to 0.01$)$ & .054 \\
\hline rs975278 (proxy) & SERPINE2 & $\mathrm{C}$ & $\mathrm{T}(0.19)$ & $\mathrm{FEV}_{1}$ & $-0.72(-1.33$ to -0.11$)$ & .021 \\
\hline \multirow[t]{2}{*}{ rs 1032295} & $H H I P$ & $\mathrm{~T}$ & $\mathrm{G}(0.40)$ & $\mathrm{FEV}_{1}$ & & \\
\hline & & & & FVC & & \\
\hline \multirow[t]{2}{*}{ rs 1828591} & HHIP & A & $\mathrm{G}(0.40)$ & $\mathrm{FEV}_{1}$ & & \\
\hline & & & & FVC & & \\
\hline rs2070600 & $A G E R$ & $\mathrm{C}$ & $\mathrm{T}(0.07)$ & $\mathrm{FEV}_{1} / \mathrm{FVC}$ & $-0.71(-1.27$ to -0.16$)$ & .012 \\
\hline rs17368659 (proxy) & MMP12 & G & $\mathrm{T}(0.13)$ & $\mathrm{FEV}_{1} / \mathrm{FVC}$ & & \\
\hline
\end{tabular}

Results are presented as the mean difference in $\mathrm{FEV}_{1}$ or FVC percent predicted per effect allele (additive genetic model). Only results with $P$ values of less than .10 are shown. $A \leftrightarrow T$, Genotyped on the opposite strand; $M A F$, minor allele frequency; $P$-int, $P$ value interaction term.

presence of 2 risk alleles of this nonsynonymous SNP in the gene coding for the receptor for advanced glycation end products $(R A G E)$ has been reported to be strongly associated with higher levels of soluble forms of this protein in a Dutch population. ${ }^{34}$ $R A G E$ expression is most abundant in the lung, and the intensity of expression in respiratory epithelial cells varies during lung morphogenesis. ${ }^{35}$ It has been shown to play a role in critical processes directly involved in perinatal transitioning of the embryonic lung into a mature functional organ. ${ }^{35}$

Hedgehog-interacting protein $(H H I P)$ has been implicated in organ development and repair in multiple tissues ${ }^{36}$ and is therefore a strong candidate gene for COPD. Our findings of HHIP SNP rs1828591 risk alleles being associated with an increased risk of TEW and lower lung function support our hypothesis.

In addition, we have made an intriguing observation that for some genes exposure effects on lung function were only observed in children without or with only 1 risk allele or alleles of genes known to be associated with COPD. As a result, COPD risk alleles of these genes were associated with better lung function in exposed children. We have observed these effects in PIAMA for SERPINE2, HHIP, and TGFB1, genes that are all strong candidates for our hypothesis because they play an important role in lung morphogenesis. ${ }^{1,23,37,38}$ A significant interaction in the same direction was only replicated for HHIP in ALSPAC. Therefore we cannot exclude that these findings are false positive. Further research has to be performed because the exposure effects were not minor. Adverse effects of $4 \%$ to $9 \%$ in $\mathrm{FEV}_{1}$ percent predicted with in utero exposure were observed in PIAMA children without COPD-related genotypes. If these observations are replicated in future studies and found for other genes replicated as well, we put forward that this might be due to the fact that genetic effects during lung development in utero might be different from effects at adult age, where the lung has been fully developed and effects might be targeting lung tissue destruction.

Our hypothesis was that COPD genes influence early lung development, such as branching morphogenesis in utero, hence showing an indirect relationship with TEW, a marker of lower lung function. Alternatively, COPD genes might influence susceptibility to early-life respiratory tract infections leading to TEW without a relationship with later COPD. However, we did not observe a direct relationship of TNS1 and HHIP with the occurrence of lower respiratory tract infections in PIAMA (data not shown), making this alternative explanation of the association of these genes with TEW unlikely.

Low lung function in childhood is not specific for COPD and can also be caused by other diseases, such as bronchopulmonary dysplasia, cystic fibrosis, and asthma. ${ }^{39}$ Furthermore, some of the genes we have studied are associated not only with COPD but also with asthma. ${ }^{40-42}$ We cannot fully exclude that observed associations with lung function in our birth cohort might be ascribed to asthma. However, this is unlikely because none of the SNPs were associated with doctor-diagnosed asthma at age 8 years (data not shown). Our findings support the general concept of the "Dutch hypothesis" by showing common genetic origins of obstructive airway disease in childhood and COPD at older age related to environmental pressure. ${ }^{4}$

Our aim was to detect all possible relevant associations of variants in the 15 COPD genes with any of the outcome parameters. We acknowledge that our strategy of avoiding type II errors implies accepting a higher risk of type I errors. We have calculated the probability of observing a $P$ value as small as our minimum $P$ value under the null hypothesis of no main associations to be $20 \%{ }^{43}$ Thus we cannot fully exclude that some of the statistically significant test results observed in the PIAMA study are false positive because of multiple testing. Because the effect sizes we actually found were at a level that would be very relevant, we evaluated our positive findings in the larger ALSPAC cohort. We are convinced that we have found evidence that at least some of the genes known to be involved in COPD play a role in lung function development and growth in childhood. Otherwise, it would be very unlikely to find so many statistically significant associations. For example, the probability to find 10 or more significant main associations with any of the outcomes for the 20 SNPs by chance in PIAMA would be only $0.7 \%$. Further research on this topic has to be performed to pinpoint the variants in the genes studied and the underlying mechanisms.

Because our aim was to link childhood lung function with adult COPD, we have chosen to limit our study to SNPs previously associated with COPD that mostly emerged from studies covering the complete gene by haplotype tagging SNPs. Because of this strategy, we cannot exclude that other functional genetic variants in the genes that were not related to COPD associate with childhood lung function or TEW. 


\begin{tabular}{|c|c|c|c|c|c|}
\hline \multicolumn{6}{|c|}{ Mean difference $(95 \% \mathrm{Cl})$ in lung function per COPD risk allele (in presence or absence of exposure) } \\
\hline \multicolumn{3}{|c|}{ Maternal smoking pregnancy } & \multicolumn{3}{|c|}{ ETS exposure first year } \\
\hline Yes & No & $P$-int & Yes & No & $P$-int \\
\hline$-0.93(-2.14$ to 0.28$)$ & $0.29(-0.26$ to 0.85$)$ & .065 & $-0.91(-1.94$ to 0.12$)$ & $0.33(-0.38$ to 1.04$)$ & .047 \\
\hline & & & $0.50(-0.50$ to 1.51$)$ & $-0.73(-1.44$ to -0.03$)$ & .046 \\
\hline $1.12(0.08$ to 2.16$)$ & $-0.52(-1.01$ to 0.03$)$ & .005 & & & \\
\hline
\end{tabular}

We had enough statistical power to find relevant differences in lung function levels and occurrence of symptoms between genotypes. For example, we had more than $90 \%$ statistical power to find additive effects on $\mathrm{FEV}_{1}$ of $2 \%$ per allele in PIAMA children at an $\alpha$ value of .05. However, a reason why the findings from the PIAMA study could not be replicated in KOALA could be that the number of lung function measurements in KOALA was too small to detect relatively small effects $(<5 \%)$ under a recessive mode of inheritance, as observed in PIAMA. Moreover, lung function was measured at a younger age in KOALA, and we observed many differences in characteristics between both studies that might have played a role. The exceptionally low prevalence of maternal smoking during pregnancy in the KOALA cohort might have hampered the statistical power to find interactions in this study.

Because KOALA did not collect data on the third year of life, TEW could not be defined by using the standard definition of wheeze in the first 3 years and not at age 6 years. ${ }^{11}$ However, the results were not altered when using this definition in PIAMA or when analyzing TEW as the outcome, which is one of the previously identified and validated phenotypes from longitudinal latent class analysis in PIAMA (data not shown). ${ }^{44}$ In the analyses on TEW we have excluded children with symptoms of wheeze at school age (5.6\% with late onset and $11.4 \%$ with persistent wheeze in PIAMA), an outcome known to be closely related to asthma and allergic sensitization. ${ }^{11}$ This might have affected the results. However, analyses, including these children in the reference group produced similar results with significant ORs for TNS 1 (OR, 1.23 [95\% CI, 1.04 to 1.25]) and HHIP (OR, 1.33 [95\% CI, 1.13 to 1.57]), showing the robustness of our findings.

A challenge to directly assess relationships between COPD genes, early lung function deficits, and COPD is to overcome the long time period between early childhood events and COPD onset. This might require long-term follow-up or, alternatively, well-documented historical data on relevant exposures and wheeze history in retrospective cohorts or case-control studies of COPD onset with genotyping of the relevant genes.

In summary, our results support the general hypothesis that COPD has its origins in early childhood by demonstrating associations between several important COPD-associated genes and transient early symptoms of wheeze and lower lung function in the PIAMA and ALSPAC studies. These effects were not minor. Differences of $4 \%$ to $7 \%$ in $\mathrm{FEV}_{1}$ percent predicted between children with and without the COPD genotypes were observed in PIAMA children exposed to maternal smoking during pregnancy. Our results suggest that COPD genes are involved in the infant's lung response to maternal smoking during pregnancy.

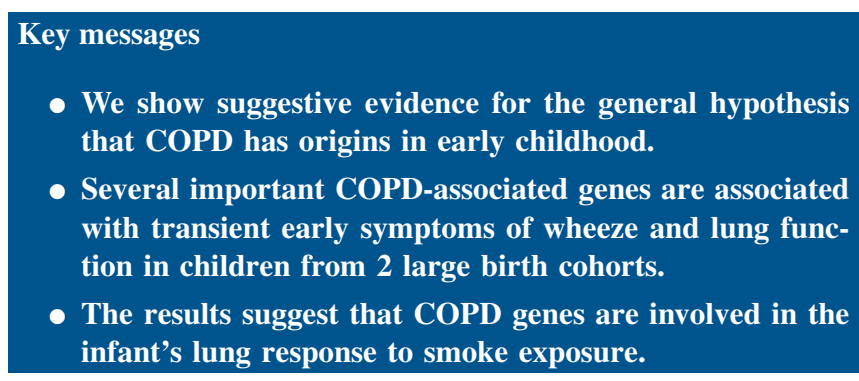

\section{REFERENCES}

1. Warburton D, Gauldie J, Bellusci S, Shi W. Lung development and susceptibility to chronic obstructive pulmonary disease. Proc Am Thorac Soc 2006;3:668-72.

2. Bush A. COPD: A pediatric disease. COPD 2008;5:53-67.

3. Silverman M, Kuehni CE. Early lung development and COPD. Lancet 2007;370: 717-9.

4. Postma DS, Kerkhof M, Boezen HM, Koppelman GH. Asthma and chronic obstructive pulmonary disease: common genes, common environments? Am J Respir Crit Care Med 2011;183:1588-94.

5. Ciencewicki J, Trivedi S, Kleeberger SR. Oxidants and the pathogenesis of lung diseases. J Allergy Clin Immunol 2008;122:456-68.

6. Landau L. Tobacco smoke exposure and tracking of lung function into adult life. Paediatr Respir Rev 2008;9:39-44.

7. Jones LL, Hashim A, McKeever T, Cook DG, Britton J, Leonardi-Bee J. Parental and household smoking and the increased risk of bronchitis, bronchiolitis and other lower respiratory infections in infancy: systematic review and meta-analysis. Respir Res 2011;12:5.

8. Cook D, Strachan D, Carey I. Health effects of passive smoking. 9: Parental smoking and spirometric indices in children. Thorax 1998;53:884-93.

9. Svanes C, Sunyer J, Plana E, Dharmage S, Heinrich J, Jarvis D, et al. Early life origins of chronic obstructive pulmonary disease. Thorax 2010;65:14-20.

10. Martinez FD. Development of wheezing disorders and asthma in preschool children. Pediatrics 2002;109:362-7.

11. Martinez FD, Wright AL, Taussig LM, Holberg CJ, Halonen M, Morgan WJ. Asthma and wheezing in the first six years of life. N Engl J Med 1995;332:133-8.

12. Stern DA, Morgan WJ, Wright AL, Guerra S, Martinez FD. Poor airway function in early infancy and lung function by age 22 years: A non-selective longitudinal cohort study. Lancet 2007;370:758-64.

13. Morgan WJ, Stern DA, Sherrill DL, Guerra S, Holberg CJ, Guilbert TW, et al. Outcome of asthma and wheezing in the first 6 years of life: follow-up through adolescence. Am J Respir Crit Care Med 2005;172:1253-8. 
14. Henderson J, Granell R, Heron J, Sherriff A, Simpson A, Woodcock AA, et al. As sociations of wheezing phenotypes in the first six years of life with atopy, lung function and airway responsiveness in mid childhood. Thorax 2008;63:974-80.

15. van Diemen C, Postma D, Vonk J, Bruinenberg M, Schouten J, Boezen HM. A disintegrin and metalloprotease 33 polymorphisms and lung function decline in the general population. Am J Respir Crit Care Med 2005;172:329-33.

16. Reijmerink NE, Kerkhof M, Koppelman GH, G J, de Jongste JC, Smit HA, et al. Smoke exposure interacts with ADAM33 polymorphisms in the development of lung function and hyperresponsiveness. Allergy 2009;64:898-904.

17. Brunekreef B, Smit HA, de Jongste JC, Neijens HJ, Gerritsen J, Postma DS, et al. The Prevention and Incidence of Asthma and Mite Allergy (PIAMA) birth cohort study: design and first results. Pediatr Allergy Immunol 2002;13:55-60.

18. Kummeling I, Thijs C, Penders J, Snijders BE, Stelma F, Reimerink J, et al. Etiology of atopy in infancy: the KOALA birth cohort study. Pediatr Allergy Immunol 2005; $16: 679-84$

19. Boyd A, Golding J, Macleod J, Lawlor DA, Fraser A, Henderson J, et al. Cohort profile: The 'children of the 90s'-the index offspring of the Avon Longitudinal Study of Parents and Children. Int J Epidemiol 2013;42:111-27.

20. Smolonska J, Wijmenga C, Postma DS, Boezen HM. Meta-analyses on suspected COPD genes-a summary of 20 years' research. Am J Respir Crit Care Med 2009; 180:618-31.

21. Hersh CP, DeMeo DL, Lange C, Litonjua AA, Reilly JJ, Kwiatkowski D, et al. Attempted replication of reported chronic obstructive pulmonary disease candidate gene associations. Am J Respir Cell Mol Biol 2005;33:71-8.

22. Repapi E, Sayers I, Wain L, Burton P, Johnson T, Obeidat M, et al. Genome-wide association study identifies five loci associated with lung function. Nat Genet 2010; 42:36-44.

23. DeMeo DL, Mariani TJ, Lange C, Srisuma S, Litonjua AA, Celedon JC, et al. The SERPINE2 gene is associated with chronic obstructive pulmonary disease. Am J Hum Genet 2006;78:253-64.

24. Zhu G, Warren L, Aponte J, Gulsvik A, Bakke P, the International COPD Genetics Network (ICGN) Investigators, et al. The SERPINE2 gene is associated with chronic obstructive pulmonary disease in two large populations. Am J Respir Crit Care Med 2007;176:167-73.

25. Cho M, Boutaoui N, Klanderman B, Sylvia J, Ziniti J, Hersh C, et al. Variants in FAM13A are associated with chronic obstructive pulmonary disease. Nat Genet 2010;42:200-2

26. Hancock D, Eijgelsheim M, Wilk J, Gharib S, Loehr L, Marciante K, et al. Metaanalyses of genome-wide association studies identify multiple loci associated with pulmonary function. Nat Genet 2010;42:45-52.

27. Wilk J, Chen T, Gottlieb D, Walter R, Nagle M, Brandler B, et al. A genome-wide association study of pulmonary function measures in the Framingham Heart Study. PLoS Genet 2009;5:e1000429.

28. Pillai SG, Ge D, Zhu G, Kong X, Shianna KV, Need AC, et al. A genome-wide association study in chronic obstructive pulmonary disease (COPD): identification of two major susceptibility loci. PLoS Genet 2009;5:e1000421.
29. Hunninghake GM, Cho MH, Tesfaigzi Y, Soto-Quiros ME, Avila L, Lasky-Su J, et al. MMP12, lung function, and COPD in high-risk populations. N Engl J Med 2009;361:2599-608.

30. DeMeo D, Mariani T, Bhattacharya S, Srisuma S, Lange C, Litonjua A, et al. Integration of genomic and genetic approaches implicates IREB2 as a COPD susceptibility gene. Am J Hum Genet 2009;85:493-502.

31. The International HapMap Consortium. A haplotype map of the human genome. Nature 2005;437:1299-320.

32. Stanojevic S, Wade A, Cole TJ, Lum S, Custovic A, Silverman M, et al. Spirometry centile charts for young Caucasian children: the asthma UK collaborative initiative. Am J Respir Crit Care Med 2009;180:547-52.

33. Soler Artigas M, Wain LV, Repapi E, Obeidat M, Sayers I, Burton PR, et al. Effect of 5 genetic variants associated with lung function on the risk of COPD, and their joint effects on lung function. Am J Respir Crit Care Med 2011;184:786-95.

34. Gaens KHJ, Ferreira I, van der Kallen CJH, van Greevenbroek MMJ, Blaak EE, Feskens EJM, et al. Association of polymorphism in the receptor for advanced glycation end products (RAGE) gene with circulating RAGE levels. J Clin Endocrinol Metab 2009;94:5174-80

35. Reynolds PR, Kasteler SD, Cosio MG, Sturrock A, Huecksteadt T, Hoidal JR. RAGE: Developmental expression and positive feedback regulation by egr-1 during cigarette smoke exposure in pulmonary epithelial cells. Am J Physiol Lung Cell Mol Physiol 2008;294:L1094-101.

36. Shi W, Chen F, Cardoso WV. Mechanisms of lung development: contribution to adult lung disease and relevance to chronic obstructive pulmonary disease. Proc Am Thorac Soc 2009;6:558-63.

37. Greenlee KJ, Werb Z, Kheradmand F. Matrix metalloproteinases in lung: Multiple, multifarious, and multifaceted. Physiol Rev 2007;87:69-98.

38. Alejandre-Alcazar MA, Michiels-Corsten M, Vicencio AG, Reiss I, Ryu J, de Krijger RR, et al. TGF-beta signaling is dynamically regulated during the alveolarization of rodent and human lungs. Dev Dyn 2008;237:259-69.

39. Postma DS, Brusselle G, Bush A, Holloway JW. I have taken my umbrella, so of course it does not rain. Thorax 2012;67:88-9.

40. Himes BE, Klanderman B, Ziniti J, Senter-Sylvia J, Soto-Quiros ME, Avila L, et al. Association of SERPINE2 with asthma. Chest 2011;140:667-74.

41. Zhang Y, Zhang J, Huang J, Li X, He C, Tian C, et al. Polymorphisms in the transforming growth factor-betal gene and the risk of asthma: a meta-analysis. Respirology 2010;15:643-50.

42. Li X, Howard TD, Moore WC, Ampleford EJ, Li H, Busse WW, et al. Importance of hedgehog interacting protein and other lung function genes in asthma. J Allergy Clin Immunol 2011;127:1457-65.

43. Conneely KN, Boehnke M. So many correlated tests, so little time! Rapid adjustment of P values for multiple correlated tests. Am J Hum Genet 2007;81:1158-68.

44. Savenije OE, Granell R, Caudri D, Koppelman GH, Smit HA, Wijga A, et al. Comparison of childhood wheezing phenotypes in 2 birth cohorts: ALSPAC and PIAMA. J Allergy Clin Immunol 2011;127:1505-12.e14. 


\section{METHODS}

\section{Study population: PIAMA}

Recruitment of participants took place in 1996-1997 through 52 antenatal clinics in 3 different regions: the north (Groningen and surroundings), central (Utrecht and Wageningen), and southwest (Rotterdam) of The Netherlands. A total of 4146 pregnant women were recruited from the general population by using a validated short screening questionnaire, and their children were followed from birth in 1996-1997. Children from mothers reporting symptoms of allergic disease were defined as high risk. All these 1327 children and a random sample of 663 children from nonallergic mothers were selected for lung function measurements. Spirometry was successfully performed in 1058 children at age 8 years. Genotypes were obtained from 1996 children from PIAMA after exclusion of 53 children from non-Dutch mothers. Complete data on genotypes and spirometry were available from 914 children.

The medical ethics committees approved the study, and all participants provided written informed (parental) consent.

\section{Study population: KOALA}

For the KOALA birth cohort, 2343 children from healthy pregnant women were recruited in weeks 10 to 14 of pregnancy from an ongoing prospective cohort study on pregnancy-related pelvic girdle pain. In addition, pregnant women were recruited through posters in organic food shops, anthroposophical physicians' offices, and midwives at 10 to 14 weeks of pregnancy; these subjects comprised the alternative recruitment group $(n=491)$. Recruitment of participants took place in 2001-2003 in the south of The Netherlands. Children of women who had provided blood samples in pregnancy and had subsequent home visits at age 2 years $(n=829)$ were candidates for home visits at age 6 to 7 years. Spirometry was measured in 443 of these children. Genotypes were obtained from 1572 children from KOALA after exclusion of 71 children from non-Dutch mothers. Complete data on genotypes and spirometry were available from 366 children.

\section{Study population: ALSPAC}

ALSPAC is a longitudinal, population-based birth cohort study that recruited pregnant women residing in Avon, United Kingdom, with expected dates of delivery from April 1, 1991, to December 31, 1992. The study methodology has been described in detail previously. ${ }^{\mathrm{E} 1}$ Ethical approval was obtained from the ALSPAC Law and Ethics Committee and the local research ethics committees. Further details of the ALSPAC study are available at: http://www.bristol.ac.uk/alspac.

TEW was defined at 6, 18, 42 and 69 months after birth based on responses to the following question: "In the past 12 (6 for first questionnaire) months has (your child) had wheezing/wheezing with whistling on the chest?"

\section{Genotyping in PIAMA and KOALA}

Genotyping in PIAMA and KOALA was performed by means of competitive allele-specific PCR with KASPar genotyping chemistry (K-Biosciences, Herts, United Kingdom). The genotype frequencies did not deviate significantly from Hardy-Weinberg equilibrium $(P<.002)$.

\section{Genotyping in ALSPAC}

Genotyping was carried out at 2 different centers (the Wellcome Trust Sanger Centre, Cambridge, United Kingdom, and Laboratory Corporation of America, Burlington, NC) by using the Illumina HumanHap 550 array (Illumina, San Diego, Calif). Subjects were excluded on the basis of the following: sex mismatches, minimal or excessive heterozygosity, disproportionate levels of individual missingness ( $>3 \%)$, cryptic relatedness measured as a proportion of identity by descent (IBD $>0.1$ ), and insufficient sample replication (IBD $<0.8)$. The remaining subjects were assessed for evidence of population stratification by using multidimensional scaling analysis and compared with HapMap II (release 22) European descent (CEU), Han Chinese, Japanese, and Yoruba reference populations; all subjects with nonEuropean ancestry were removed. SNPs with a minor allele frequency of less than $1 \%$, a call rate of less than $95 \%$, or evidence for violations of HardyWeinberg equilibrium $\left(P<5 \times 10^{-7}\right)$ were removed. Autosomal genotypic data were subsequently imputed with Markov Chain Haplotyping software (MACH v.1.0.16, Li et $\mathrm{al}^{\mathrm{E} 2}$ ) and phased haplotype data from CEU subjects (HapMap release 22, phase II NCBI B36, dbSNP 126) based on a cleaned dataset of 8,365 subjects and 464,311 autosomal SNPs. After imputation, all SNPs with indications of poor imputation quality $\left(r^{2}<0.30\right)$ were removed.

\section{Lung function measurements}

A Jaeger pneumotachograph (Viasys Healthcare) was used for lung function testing in PIAMA. In ALSPAC and KOALA spirometry was performed with the Vitalograph Spirotrac IV system (Vitalograph, Maids Moreton, United Kingdom) and the handheld Medikro Spirostar USB spirometer (Medikro, Kuopio, Finland), respectively, by using methods described previously. ${ }^{\mathrm{E} 3 \mathrm{E} 4}$ The machines were calibrated every day on which medical examinations took place. FVC and $\mathrm{FEV}_{1}$ were measured in the sitting position while wearing a nose clip by trained personnel according to the American Thoracic Society/European Respiratory Society guidelines. ${ }^{\text {E5 }}$ For each child, at least 3 acceptable maneuvers had to be obtained. The best results of 3 acceptable and repeatable (FVC $\pm 150 \mathrm{~mL}$ ) flow-volume curves were accepted after post hoc quality control by a respiratory physician.

\section{RESULTS \\ Main associations of outcomes with exposure in KOALA and ALSPAC}

Maternal smoking during pregnancy increased the risk of TEW in KOALA (OR, 3.0 [95\% CI, 1.5 to 5.8]; $P=.001$ ) and ALSPAC (OR, 1.3 [95\% CI, 1.1 to 1.6$] ; P=.001$ ). Maternal smoking during pregnancy was not significantly associated with $\mathrm{FEV}_{1}$ $(-3.2 \%$ [95\% CI, $-9.0 \%$ to $2.6 \%] ; P=.28)$ or $\mathrm{FVC}(-3.6 \%$ [95\% CI, $-9.5 \%$ to $2.2 \%$ ]; $P=.22$ ) in KOALA or ALSPAC $\left(\mathrm{FEV}_{1}:-0.62 \%\right.$ [95\% CI, $-1.47 \%$ to $\left.0.23 \%\right] ; P=.15$; FVC: $0.48 \%$ [ $95 \% \mathrm{CI},-0.38 \%$ to $1.34 \%] ; P=.28$ ). ETS exposure in the vicinity of the child (KOALA) after birth was not significantly associated with TEW or lung function levels in KOALA. In ALSPAC parental smoking during the first year of life was significantly associated with TEW (OR, 1.2 [95\% CI, 1.0 to 1.4]; $P=.03$ ) but not with $\mathrm{FEV}_{1}$ (OR, $0.53 \%[95 \% \mathrm{CI},-1.35 \%$ to $0.29 \%$ ]; $P=.20$ ) or FVC (OR, $0.35 \%$ [95\% CI, $-0.48 \%$ to $1.18 \%] ; P=.41)$.

\section{REFERENCES}

E1. Boyd A, Golding J, Macleod J, Lawlor DA, Fraser A, Henderson J, et al. Cohort profile: The 'children of the 90s' - the index offspring of the Avon Longitudinal Study of Parents and Children. Int J Epidemiol 2013;42:111-27.

E2. Li Y, Willer CJ, Ding J, Scheet P, Abecasis GR. MaCH: using sequence and genotype data to estimate haplotypes and unobserved genotypes. Genet Epidemiol 2010;34:816-34.

E3. Kotecha SJ, Watkins WJ, Heron J, Henderson J, Dunstan FD, Kotecha S Spirometric lung function in school-age children: effect of intrauterine growth retardation and catch-up growth. Am J Respir Crit Care Med 2010;181:969-74.

E4. Cremers E, Thijs C, Penders J, Jansen E, Mommers M. Maternal and child's vitamin D supplement use and vitamin D level in relation to childhood lung function: the KOALA Birth Cohort Study. Thorax 2011;66:474-80.

E5. Miller MR, Hankinson J, Brusasco V, Burgos F, Casaburi R, Coates A, et al. Standardisation of spirometry. Eur Respir J 2005;26:319-38. 
76.e2 KERKHOF ET AL

TABLE E1. Linkage disequilibrium ( $r^{2}$ values) between SNPs within loci

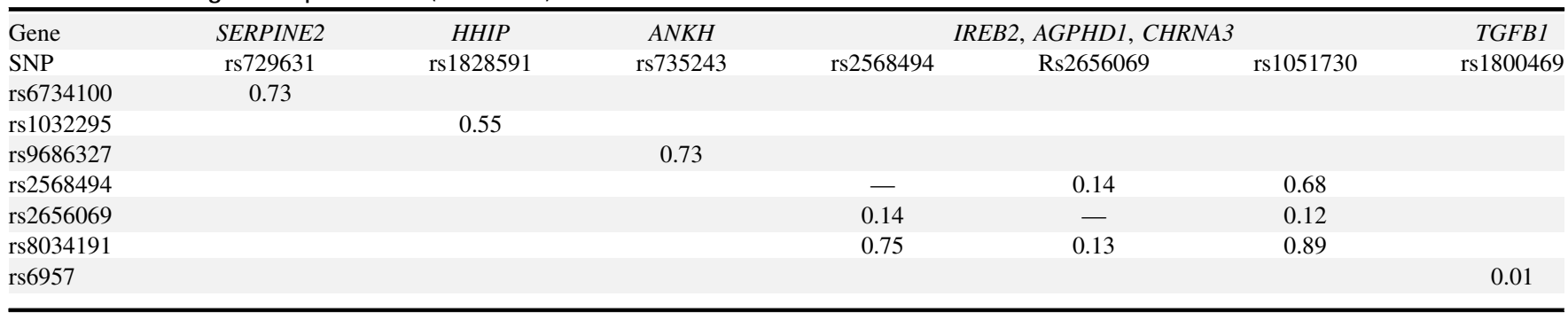


TABLE E2. Association of SNPs in known COPD genes with TEW, FEV $1, F V C$, and FEV $/$ FVC ratio in the KOALA study

\begin{tabular}{|c|c|c|c|c|c|c|}
\hline SNP & Nearest gene & Effect allele & Genetic model & Trait & Effect $(95 \% \mathrm{Cl})$ & $P$ value \\
\hline rs 2571445 & TNS1 & $\mathrm{T}$ & Additive & TEW & $0.91(0.73$ to 1.14$)$ & .42 \\
\hline \multirow[t]{2}{*}{ rs6734100 } & SERPINE2 & $\mathrm{C}$ & Dominant & $\mathrm{FEV}_{1}$ & $-1.34(-10.7$ to 8.01$)$ & .78 \\
\hline & & & & FVC & $-0.56(-9.96$ to 8.85$)$ & .91 \\
\hline rs729631 & & & & FVC & $1.18(-4.92$ to 7.29$)$ & .70 \\
\hline \multirow[t]{2}{*}{ rs7671167 } & $F A M 13 A$ & $\mathrm{~T}$ & Recessive & $\mathrm{FEV}_{1}$ & $2.39(-0.72$ to 5.50$)$ & .13 \\
\hline & & & & FVC & $1.76(-1.37$ to 4.89$)$ & .27 \\
\hline rs2276109 & MMP12 & A & Dominant & FVC & $5.97(-10.3$ to 22.2$)$ & .47 \\
\hline
\end{tabular}

Results are presented as ORs for TEW and as the mean difference in $\mathrm{FEV}_{1}$ or FVC percent predicted between children with and without the effect genotype. 
TABLE E3. Replication results of SNPs in COPD genes interacting with maternal smoking during pregnancy or environmental smoke exposure in the first year of life in KOALA

\begin{tabular}{|c|c|c|c|c|c|c|c|c|c|c|}
\hline \multirow[b]{3}{*}{ SNP } & \multirow[b]{3}{*}{ Nearest gene } & \multirow{3}{*}{$\begin{array}{l}\text { Effect } \\
\text { allele }\end{array}$} & \multirow{3}{*}{$\begin{array}{l}\text { Genetic } \\
\text { model }\end{array}$} & \multirow[b]{3}{*}{ Trait } & \multicolumn{6}{|c|}{ Effect $(95 \% \mathrm{Cl})$ of genotype on lung function (in presence or absence exposure) } \\
\hline & & & & & \multicolumn{3}{|c|}{ Maternal smoking during pregnancy } & \multicolumn{3}{|c|}{ Environmental smoke in first year } \\
\hline & & & & & Yes & No & $P$-int & Yes & No & $P$-int \\
\hline rs 2571445 & TNS1 & $\mathrm{T}$ & Recessive & $\mathrm{FEV}_{1}$ & & & & $\begin{array}{c}1.86 \\
(-9.33 \text { to } 13.0)\end{array}$ & $\begin{array}{c}-0.25 \\
(-4.43 \text { to } 3.93)\end{array}$ & .73 \\
\hline rs 729631 & SERPINE2 & $\mathrm{C}$ & Recessive & $\mathrm{FVC}$ & $\begin{array}{c}1.76 \\
(-15.4 \text { to } 18.9)\end{array}$ & $\begin{array}{c}-3.78 \\
(-6.11 \text { to }-0.45)\end{array}$ & .57 & $\begin{array}{c}-1.25 \\
(-9.23 \text { to } 6.73)\end{array}$ & $\begin{array}{c}-3.31 \\
(-6.37 \text { to }-0.25)\end{array}$ & .64 \\
\hline \multirow[t]{2}{*}{ rs 1032295} & $H H I P$ & $\mathrm{~T}$ & Dominant & $\mathrm{FEV}_{1}$ & $\begin{array}{c}1.90 \\
(-21.7 \text { to } 25.5)\end{array}$ & $\begin{array}{c}-0.01 \\
(-3.72 \text { to } 3.70)\end{array}$ & .88 & & & \\
\hline & & & & $\mathrm{FEV}_{1} / \mathrm{FVC}$ & $\begin{array}{c}-1.39 \\
(-15.1 \text { to } 12.3)\end{array}$ & $\begin{array}{c}-1.69 \\
(-3.83 \text { to } 0.45)\end{array}$ & .97 & & & \\
\hline \multirow[t]{2}{*}{ rs1828591 } & HНIP & A & Dominant & $\mathrm{FEV}_{1}$ & $\begin{array}{c}1.90 \\
(-21.9 \text { to } 25.7)\end{array}$ & $\begin{array}{c}0.29 \\
(-3.53 \text { to } 4.09)\end{array}$ & .90 & & & \\
\hline & & & & $\mathrm{FEV}_{1} / \mathrm{FVC}$ & $\begin{array}{c}-1.39 \\
(-14.9 \text { to } 12.1)\end{array}$ & $\begin{array}{c}-0.72 \\
(-2.87 \text { to }-1.43)\end{array}$ & .92 & & & \\
\hline \multirow[t]{2}{*}{ rs6957 } & $T G F B 1$ & $\mathrm{C}$ & Dominant & $\mathrm{FEV}_{1}$ & $\begin{array}{c}4.20 \\
(-8.89 \text { to } 17.3)\end{array}$ & $\begin{array}{c}-1.52 \\
(-4.39 \text { to } 1.34)\end{array}$ & .40 & & & \\
\hline & & & & FVC & $\begin{array}{c}-2.97 \\
(-16.2 \text { to } 10.2)\end{array}$ & $\begin{array}{c}-1.33 \\
(-4.22 \text { to } 1.56)\end{array}$ & .81 & & & \\
\hline
\end{tabular}

Results are presented as the mean difference in $\mathrm{FEV}_{1}$ or FVC percent predicted between children with and without the effect genotype.

$P$-int, $P$ value interaction term.

$P<.05$ (boldface). 